\title{
DAMPAK COVID19 TERHADAP MANAJEMEN OPERASIONAL UMKM SEKITAR KAMPUS UNIVERSITAS NEGERI PADANG (UNP)
}

\section{RIKA SEPTRIZARTY, ASRUL MULYADIN}

Administrasi Bisnis, STIA Adabiah

rikaseptrizary04@gmail.com, asrul_mulyadin@yahoo.com

\begin{abstract}
Pandemi of Covid19 changed human activities. The change can be analyzed in campus life, from offline study to online study. The campus is used to be a central of activities and financial support for people around turned become the low mobility area. Covid-19 get the big impact to the Small Medium Enterprise (SME) located around campus. This resecarh aims to analyzed the impact of covid-19 to the operational management of SME located araund UNP (Padang State University) and used qualititive method by in depth inetrview. The result of the research, only 30\% of SME's operated during pandemi . the significant impact is the reducing of operational schedule and caused the reducing of human resourcellabour/staff. Another findings, the SME's relocated to the near of communities area and even change the type of business.
\end{abstract}

Keywords: Operasional Management, Pandemi, Covid19, SME

\begin{abstract}
Abstrak: Pandemi Covid 19 membuat semua aktivitas manusia menjadi terbatas dan berubah. Perubahan ini terutama dialami dunia kampus, dimana perkulaiahan tatap muka berubah menjadi perkuliahan online. Kampus yang sejatinya menjadi pusat kegiatan dan menunjang perekonomian di daerah kampus berubah menjadi daerah yang memiliki mobilitas rendah. UMKM yang berada di sekitar kampus menjadi pihak yang paling rentan dan mendapat dampak yang siknifikan dari pandemi ini. Penelitian ini bertujuan untuk menganalisa dampak covid19 terhadap manajemen operasional UMKM yang berada di sekitar kampus UNP yang berada di pusat kota Padang. Metode penelitain dengan pendekatan kualitatif menggunakan depth interview Dari 264 UMKM hanya 30\% yang tetap berjualan, yang lainnya memilih untuk menutup toko, atau berjualan online. Dampak yang sangat besar adalah dengan berkurangnya jadwal operasional UMKM dan pengurangan sumber daya manusia, sehingga banyaknya karyawan toko yang diberhentikan, atau minta berhenti karena menerima gaji lebih sedikit karena jam kerja dikurangi dari fulltime menjadi parttime dan juga ada yang dirumahkan. Selain itu, juga ditemukan beberapa UMKM yang pindah tempat usaha ke tempat yang lebih ramai bahkan ada juga yang mengganti usahanya dengan usaha lain yang lebih diminati konsumen.
\end{abstract}

Kata Kunci: Manajemen operasional, Pandemi, Covid19, UMKM

\section{A. Pendahuluan}

Pandemi menyebabkan situasi yang sangat kacau dalam dalam rantai pasok di seluruh dunia yang mengarahkan pada tantangan untuk bertahan. Covid19 yang masih berlangsung adalah sebuah krisis kemanusiaan yang tidak terpediksi sebelumnya yang memberikan dampak secara dinamis bagi bisnis dunia. (Farooq 2021). Dampak pandemi ini juga terasa di Indonesia, sebagai negara dengan banyak Usaha Mikro Kecil dan Menengah (UMKM). Pandemi Covid19 berdampak negatif pada sektor UMKM yang menyebabkan para pelakunya harus beradaptasi antara lain dengan menurunkan produksi barang/jasa, mengurngi junlah jam kerja karyawan serta numlah saluran penjualan//pemasaran. (Bahtiar, 2021).

Sejak merebaknya virus corona atau yang dikenal dengan Pandemi Covid-19 terjadilah penurunan omzet pelaku UMKM yang sangat signifikan. Terdapat beberapa lapagan usaha UMKM yang terkena dampak yang paling besar, yaitu penyedia akomodasi, pariwisata dan makan minum, perdagangan besar dan eceran, serta reparasi sepeda motor dan transportasi dan perdagangan. Berdasarkan data yang diolah P2E LIPI, dapak penurunan pariwisata terhadap UMKM yang bergerak dalam usaha makanan dan minumam mikro mencapai $27 \%$.

346 Lembaga Penelitian dan Penerbitan Hasil Penelitian Ensiklopedia $\quad$ E-ISSN: 2657-0300


Sedangkan dampak usaha kecil makanan dan minuman mikro mencapai 1,77\%, dan usaha menengah di angka 0,07\%. Pengaruh virus Covid 19 terhadap unit merajinan dari kayu dan rotan, usaha mikro berada di angka $17,03 \%$. Untuk usaha kecil di sektor kerajinan kayu dan rotan $1,77 \%$ dan usaha menengah $0,01 \%$. Sementara itu, konsumsi rumah tangga juga terkoreksi pada roda ekonomi termasuk pasar ritel. Hasil penelitian menunjukkan bahwa UMKM adalah jenis usaha perekonomian yang paling banyak terdampak dari Pandemi Covid-19 meliputi usaha outomotif, industri baja, peralatan listrik, industri tekstil, kerajinan dan alat berat, pariwisata. Sedangkan industri yang mampu bertahan di masa pandemi Covid19 adalah 1. UMKM yang mampu mengadaptasikan bisnisnya dalam produk-produk inovasi 2. Industri ritel yang mampu bertahan, hal ini idikarenakan sebahagian mamanfaatkan penjualan melalui marketing digital. 3 Industi lain yang mampu bertahan di masa pandemi Covid19 adalah industri yang terkait dengn pemenuhan kebutuhan dasar, antara lain listrik, air bersih, pertanian, peternakan, perkebunan, perikanan, otomoif dan perbankan. Industri yang mengalami perkembangan selama Pandemi Covid-19 adalah pangan, farmasi, teknologi informasi dan komunikasi. (Rosita 2020).

Kampus sebagai pusat kegiatan dan pusat perekonomian, dimana daerah disekitar kampus merupakan daerah dengan tingkat mobilitas yang tinggi, dimana mahasiswa tinggal dan menyewa tempat kos serta beraktivitas. UMKM yang berada di sekitar kampus menjadi pihak yang paling bnayk mendapat dampak dari pandemi ini, karena semenjak April 2020, perkuliahan di kampus dilaksanakan melalui daring (online). Daerah sekitar kampus merupakan tempat yang sangat mencolok perubahannya selama pandemi, dimana biasanya ramai terjadinya mobilitas mahasiswa dan kegiatan bisnis lainnya, selama pande, i benar-benar menjadi darah sepi yang sangat sedikit penghuninya. Mahasiswa kembali ke kampung sehingga UMKm yang berada di sekitar kampus kehilangan pasar mereka, yaitu mahasiswa tersebut. Kampus UNP memeiliki jumlah mahasiswa laki-laki sebanyak 17299 orang dan mahasiswa permupuan sebanyak 28301 orang, dengan total semua mahasisa adalah 45.600 (sumber Pd Dikti. 2022) dengan jumlah UMKM yang berada di sekitar kampus berjumlah lebih dari 264 buah. Dengan diberlakukan perkulaiahn daring, para pelaku usaha otomatis mengalami penurunan penjualan karena tidak adanya mahasiswa syang berada di sektar kampuss yang akan membeli produk/jasa yang ditawarkan.

UMKM sekitar memiliki dampak lebih besar dibandingkan UMKM yang berada di tempat lain apabila pembelajaran daring diberlakukan, karena pelanggan mereka adalah mahasiswa, sedangkan UMKM yang tidak berada disekitar kampus biasanya memiliki pelanggan atau konsumen yang berasal dari umum. Hal inilah yang mneyebabkan UMKM sekitar kampus lebih rentan mengalami kerugian dan bahkan terncam tutup. Berdasarkan dampak tersebut, penulis melakukan penelitian yang bertujuan untuk menganalisa dampak Covid19 terhadap UMKM yang berada di sekitar kampus dengan memfokuskan pada manajemen operasional. Operasional, Pemasarasan dan keuangan/akunting memrupakan tiga fungsi sasar dari semua perusahaan/organisasi. Manajer operasi adalah kunci pemain kunci dalam perperangan dalam meningkatkan produktivitas perusahaan. Manajemen operasional merupakan kegiatan-kegaitan yang berhubungan dengan menciptakan barang atau jasa melalui tranformasi input menjadi aoutpit.(Heizer. 2017).

\section{B. Metodologi Penelitian}

Pendekatan yang digunakan pada penlitian ini adalah pendekatan kualitatif dengan metode in depth interview dan memberikan kuisioner sebagai pedoman dalam melakukan wawancara. Wawancara dilakukan kepada pemilik UMKM mengenai dampak Covid-19 terhadap usaha mereka dalam rentang waktu April 2020- September 2021 dalam ruang lingkup manajemen operasional sebagai bagian dari strategi dalam penambilan keputusan untuk keberlangsungan usaha, yaitu disain barang/jasa, kualitas, proses dan kapasitas, lokasi, tata letak, sumber daya manusia dan disain kerja, manajemen rantai pasok, persediaan, penjadwalan dan, perawatan (Heizer, 2017). UMKM yang bertahan dalam rentang waktu di atas hanya berkisar 30\%, sehingga dari 264 UMKM, wawancara dilakukan kepada 50 pemilik 
UMKM. Apabila pemilik tidak ditempat, wawancara dilakukan kepada manajer operasi atau yang bertanggung jawab terhadap kegiatan UMKM. Setelah dilakukan wawancara, hasil wawancara dianalisa terhadap strategi tersebut.

\section{Hasil dan Pembahasan}

Selama pandemi terjadi, UMKM di sekitar kampus yang menjalankan waktu operaional sepeeti waktu normal hanya sebanyak $10 \%$, yaitu toko obat, barang harian, konter pulsa dan toko kacamata, sedangkan $20 \%$ lainnya buka dengan waktu opersional lebih pendek. Misalnya toko jus mulai buka setelah pukul 12 siang, yang sebelumnya buka dari jam 9 pagi. Alasan jam buka lebih siang, karena pagi hari keadaan disekitar kampus belum ramai. Keadaan baru sedikit ramai apabila sudah jam 11 siang ke atas. Berbeda dengan waktu normal, dimana jam 8 pagi aktivitas mahasiswa sudah ramai dan sudah terjadi aktivitas jual beli di toko. Selain itu ada yang memililih untuk buka di hari-hari tertentu, misalnya pada saat mahasiswa mendaftar ulang, pada saat ujian persiapan, ujian kompre untuk mahasiswa yang akan wisuda, atau pada saat ada kegiatan kampus lainnya. selain itu banyak UMKM yang memilih untuk tidak beroperasi, karena memperhitungkan aspek biaya/ongkos operasional yang tidak tercapai dengan pendapatan karena minimnya jual beli. UMKM yang tutup memilih strategi lain antara lain memilih online dari rumah, pindah tempat usaha atau bahkan ada yang pindah usaha ke bidang lain. Penjualan melalui online dilaukan oleh UMKM yang bergerak di bidang fashion, seperti toko pakaian, kosmetik dan juga makanan. Pelaku usaha ini lebih memilih melakukan kegiatan opersional usaha mereka dar rumah masing-masing untuk mengurangi ongkos operasi penjagaan toko. Selanjutnya, beberapa UMKM memilih untuk pindah lokasi ke tempat yang lebih dekat dengan gerbang kampus dengan tujuan lebih terlihat oleh mahasiswa. Bahkan ada UMKM yang pindah ke daerah pusat kota yang lebih dekat ke masyarakat umum (daerah di sekitar kampus UNP banyak dihuni pleh mahasiswa yang mengontrak rumah, sedangkan penghuni atau penduduk perumahan sekitar kampus UNP lebih sedikit dibanding jumlah mahasiswa yang mengontrak). Strategi lainnya yang dlakukan UMKM adalah beralih usaha, dengan mencontoh usaha lainnya yang tetap buka. Hal ini sebenarnya sangat berisiko, mengingat perlunya sumber daya yang bagus untuk memulai usaha, apalagi di saat pandemi dan terlebih lagi bagi yang tidak ahli di bidang yang baru tetapi hanya mencontoh karena usaha yang dicontoh tetap bertahan.

Dampak yang sangat signifikan adalah pada aspek sumberdaya manusia dan disain kerja. Langkah yang diambil UMKM dalam efesiensi kerja adalah dengan tetap mempekerjakan semua karyawannya, tetapi jam kerja diperpendek atau diberlakukan rolling kerja. Jam kerja diperpendek karena waktu opersional berubah, dengan berkurangnya jam kerja, otomatis gaji karyawan juga berkurang. Rolling kerja biasanya dilakukan dalam sebulan yang normalnya bekerja secara penuh, tetapi dengan sistem shift, pekerja dibagi dalam sebulan kerja dengan dirolling secara bergantian. Selain dengan memperpendek waktu lerja dan rolling pegawai, ada juga UMKM yang merumahkan pegawainya, dan apabila keadaan sudah normal akan dipanggil kembali. Bahkan terdapat beberapa UMKM yang memberhentikan pegawainya karena tidak sanggup untuk menggaji. Selain pemberhentian dari pemilik usaha, juga terdap pemberhentian kerja yang berasal dari pegawai itu sendiri, karena kurangnya jam kerja yang menyebabkan berkurangnya gaji sehingga tidak bisa memenuhi kebutuhan sehari-hari pegawai. Contoh pegawai yang minta berhenti adalah karyawan pada usaha fotocopy. Banyak usaha fotocopy yang tutup selama pandemi, walau ada juga beberapa yang bertahan. Banyak usaha fotocopy di sektar UNP yang memiliki toko lebih dari satu. Selama pandemi, usaha ini hanya buka di toko utama, sehingga cabang lainnya tutup. Hal ini menyebabkan gaji pegawai berkurang dan pegawai sendiri yang mengundurkan diri.

Harga prodouk juga mengalami dampak dari pandemi ini. Pelaku UMKM terpaksa harus mengurangi harga jual supaya masyarakat umum tertarik membeli. Agar dapat bertahan, pasar dari masyarat umum harus dijangkau untuk mengantikan pasar dari mahasiswa. Diskon tiap bulan diberlakukan agar menarik pelanggan baru dengan mempromosikannya melalui sosial 
media dan spanduk-spanduk yang mencolok di depan toko agar menarik bagi pengendara jalan. Harga produk yang rendah dari harga normal ini menyebabkan pelaku usaha mengurangi rantai pasok yang jauh. Barang-barang yang biasanya didatangkan dari luar pulau Sumatera, selama Pandemi ini hanya diambil dari vendor terdekat saja, sehinga jenis barang tidak bervariasi. Produk yang dijual juga masih produk-produk lama. Pelaku usaha tidak mau mengambil resiko dengan menstock barang-barang baru yang masa waktu perputarannya belum bisa dipastikan.

Pandemi yang belum bisa dipastikan kapan akan berakhir, memaksa pelaku UMKM harus membuat strategi untuk kelangsungan usaha mereka. Kelangsungan usaha ini berdampak juga dengan kelangsungan masyarakat banyak, karena para pekerja atau anak buah toko menggantungkan hidupnya pada UMKM. Usaha yang bertahan meskipun penjualan tidak seperti penjualan normal adalah usaha yang memiliki kualitas yang bagus, walaupun pelanggan UMKM berada di luar kota karena pandemi, mereka tetap berkomunikasi dan melakukan transaksi dengan online, apabila transaksi tidak bisa dilakukan online, misalnya UMKM yang menyediakan jasa, dimana pelanggan harus bertemu langsung, maka pelangan akan mengusahaka datang walaupun dari jauh. Pada saat mereka ke kampus untuk mengurus urusan kampus yang mengharuskan mereka datang, mereka kan mengupayakan untuk mampir ke toko yang mereka minati, seperti optik untuk pemeriksaan mata. Karena mereka tidak mendapatkan pelayanan dan kualitas yang memuaskan di daerah asal, pelanggan optik tersebut akan tetap mengusahakan untuk bisa ke toko untuk mengganti kacamata atau memeriksa mata apabila resep matanya sudah berubah. Usaha lain yang dilakukan UMKM untuk tetap bertahan adalah istilah "jemput bola", yaitu pelaku usaha akan mendatangi pelanggan masing-masing, menjemput pelanggan ke rumah atau tempat kerja dan juga fasilitas antar ke rumah atau tempat kerja masing-masing, baik dalam bentuk makanan, minuman, ataupun keperluan lainnya, dengan tetap mengutamakan prosedur kesehatan dalam proses pencegahan Covid-19.

\section{Penutup}

Pandemi Covid19 yang melanda dunia sangat berdampak terhadap kelangsungan UMKM di Indoensia, terutama yang berada dekat kampus. Hal ini disebabkan karena tidak adanya kegiatan di kampus yang menyebabkan terhenti pula aktivitas perekonomian UMKM karena hilangnya pangsa pasar. Dampak yang signifikan dapat dilihat dari waktu operasi, yang hanhya $10 \%$ UMKM beroperasi sama dengan keadaan norml, selebihnya beroperasi lebih pendek bahkan ada yang tidak beroperasi, tutup, pindah tempat serta ganti sektor usaha. Akibat perubahan waktu operasi tersebut, terjadi pula pengurangan karyawan secara besar-besaran akibat banyak karyawan yang dirumahkan, dirolling atau dikurangi jam kerjanya sehingga berkurang pula gaji yang diterima sehingga tidak bisa memenuhi kebutuhan hidup sehari-hari. Manager operasi harus memotar otak untuk tetap bertahan, salah satunya dengan meningkatkan kualitas dan memberikan pelayanan lebih kepada pelanggan, seperti menjemput pelanggan dan juga mengantarkan produk/jasa ke pelanggan.

\section{Daftar Pustaka}

Astralia, S.; Dampak Pandemi Covid-19 terhadap Warung makan di Lingkungan Sekitar Kampus di Kota Solo. Universitas Muhamamdiyah Surakarta. 2021.

Bahtiar, R.A Dampak Pandemi Covid19 terhadapsektor usaha mikro, kecil dan menegah serta solusinya, Ino Singkat VolXiii, No.10///Pusit/Mei/2021.

Faroog, M.U.;Hussain, A.; Masood, T,; Habib, M.S. Suuply Chain Operations manajement in pandemics: A State-of-the-Art Review Inspired by COVID-19; sustainbility2021,13, 2504. 2021.

Heizer, J,; Render, B.; Munson, C.; Operationd Management. Perason Education. America 2017.

Rosita, R. Pengaruh pandemi covid-1 yetrhadap UMKM di Indoensia. Jurnal Lentera Bisnis, Volum 9 nomor 2. November 2020. 